\title{
A Memória Como Forma de Justiça no Pensamento de Paul Ricoeur e Tzvetan Todorov
}

Rita Mattar

\section{Resumo:}

O artigo procura mostrar que a memória não se confunde com a história, ainda que ambas resguardem em comum a problemática da representação de um objeto ausente. Diante desta distinção, procura evidenciar a força e a fragilidade específicas da memória, ambas se realizando num plano eminentemente político, no qual se entrevê uma clara dimensão moral, preocupada não apenas com a busca da verdade, mas com o uso a ser feito de uma dada narrativa memorial. É esta segunda dimensão prática que, abrindo espaço para a analogia e generalização, procura resgatar o discurso memorial de seu ponto de partida multiculturalista. Apresenta-se assim uma via de universalização do particular que supera a mera afirmação identitária por meio da forma específica de memória que Todorov chama justiça.

Palavras-chave: Memória, história, dever de memória, abuso da memória, justiça. 


\section{Introdução}

Atualmente, não são poucos os historiadores europeus que concentram sua atenção no que convencionou-se chamar de tirania da história. Para alguns deles, o século XXI, ainda sob a sombra do século anterior, procura expurgar seu passado pela rememoração incessante de seus crimes e atrocidades. Do justo dever de memória à culpabilização desmesurada e estéril há um vasto gradiente de posicionamentos e formas de entender este processo, mas parece certo que a Europa pós-guerra fria assiste, desde a década de 90, a um fenômeno encarado pelos historiadores como uma explosão das políticas de memória. Monumentos, memoriais, feriados nacionais, nomes de ruas, parques e escolas são algumas dessas políticas que ganham um lugar crescente na agenda de países europeus, visando a atender às demandas de ex-combatentes de guerras diversas, imigrantes, minorias religiosas ou raciais e tantos outros grupos que integram as sociedades europeias $^{1}$ e reivindicam o reconhecimento e a celebração do seu passado.

É certo que a memória, como meio de construção identitária, data de muito antes de nossos dias e figura entre os elementos constitutivos do conceito de nação. Embora traços da preocupação do homem com o fenômeno da memória possam ser encontrados já na filosofia grega antiga, e apesar da enorme importância acordada à memória tanto no pensamento clássico quanto no medieval ${ }^{2}$, é na era contemporânea que a ideia de memória se delimita e ganha os contornos que hoje conhecemos, como objeto de políticas nacionais - e atualmente internacionais e fonte formadora e transformadora do imaginário coletivo. É desta concepção de memória que trata o presente artigo e de sua manifestação na Europa nos últimos vinte anos.

Em I882, em seu famoso discurso "O que é uma nação?” proferido na Sorbonne, Ernest Renan aponta como principais elementos constitutivos de uma nação o passado compartilhado e o desejo de alguns homens de viverem

\footnotetext{
I O paralelo com o caso brasileiro e, mais amplamente, latino-americano, no contexto de saída de regimes militares e acerto de contas com as violações aos direitos humanos neles cometidas, embora pertinente, não será traçado, sob o risco de imprecisões que este artigo não poderia sanar. Trata-se, com efeito, de momentos diversos do processo de construção memorialística, e muito do que se segue é específico do contexto europeu na medida em que neste, diferentemente da realidade brasileira, o debate acerca da memória de eventos traumáticos atingiu um grau de desenvolvimento em que a abertura a usos ideológicos traz novas problemáticas à discussão, de todo estrangeiras ao que hoje vivemos no Brasil.

2 Os retóricos latinos, para quem a lembrança não consistia apenas em evocar o passado, mas em efetuar saberes aprendidos, arrumados num espaço mental, nomeavam os processos mnemotécnicos de associação de lembranças a lugares de ars memoriae - a eles Pierre Nora deve o nome de sua famosa obra sobre a República francesa Les Lieux de mémoire. A ideia da memória como uma arte constituiu uma tradição que se estende pela Idade Média e cuja força somente será questionada pela introdução da noção de método por filósofos da Modernidade.
} 
juntos, fazendo valer a herança a todos comum. Para além de uma raça, uma língua, de interesses compartilhados ou mesmo de aspectos geográficos, o que forma uma nação, diz Renan, é um passado heroico, grandes homens, a glória de nossos ancestrais. São esses os elementos que compõem uma ideia nacional (RENAN, I882). Ora, o que vemos em nossos dias é um progressivo desfalecimento do conceito clássico de nação, tal como forjado pelos ideais da Revolução Francesa, e a dissolução de fronteiras nacionais. Diversas nações em um só país, diversos países integrando uma mesma comunidade, vive-se hoje uma insuficiência do discurso republicano clássico, centralizador e unificado, frente à mundialização cultural, política e econômica (STORA, 2007, p.47).

Curiosamente, é neste contexto de universalização de referências que a memória ganha espaço e se desenvolve como elemento de coesão, não mais de uma nação, mas de pequenos grupos. A memória se particulariza e se torna plural, havendo tantas memórias quanto grupos delas portadoras (NORA, I997, p.24). A busca pelas próprias origens e a revalorização étnicocultural se tornam elementos recorrentes numa Europa pós-colonialista, descentralizada e que assiste ao aumento da parcela de imigrantes em sua população.

Dentre os motivos que levam a este recrudescimento memorial, há quem aponte o fim da guerra fria como elemento central nesta nova direção que tomaram as políticas de memória. A crise mundial das ideologias coletivas, marcada pela queda do mudo de Berlim em I989 e o fim da União Soviética em I99I, provocou um questionamento do marxismo e, em seguida, das ideologias nascidas do processo de descolonização, como o terceiro-mundismo (STORA, 2007, p.40) O fim da aceitação massiva de uma concepção materialista da história coincide com o fortalecimento de análises multiculturalistas, incapazes de oferecer uma noção de história que encadeie todos os tempos sob um único denominador comum. Em outras palavras, vivemos hoje uma crise das grandes narrativas. Mais ainda, para além de uma incredulidade em relação às metanarrativas em razão do multiculturalismo, o que hoje vemos é o fim inclusive das próprias narrativas nacionais (GUILLEBAUD, 2006, p.69)

Esse contexto de crise da política leva ao que Benjamin Stora chama de tribalização do político, isto é, um encerramento dos indivíduos na esfera privada, um refúgio no passado e, portanto, na memória. "Em face da ausência de um grande projeto político mobilizador, assiste-se ao encerramento em comunidades religiosas, culturais ou étnicas" (STORA, 2007: p. 40). Enquanto os anos 50 a 80 viram grupos sociais e intelectuais se posicionarem ativamente criticando o Estado, hoje vemos esses grupos se apresentarem essencialmente como vítimas 
e demandarem do Estado o reconhecimento da sua dor. E o principal efeito desta transformação é o desenvolvimento, em todo o mundo, de fenômenos de memória.

É neste contexto de crescimento da demanda de grupos organizados em torno do reconhecimento de seu passado que se fala em dever de memória, contrapartida do direito à memória. As discussões em torno do assunto são diversas, na medida em que vão desde a legitimidade de tal direito até à melhor forma de implementação deste. Em 1990 a lei Gayssot, sobre crimes contra a humanidade, gerou na França um acalorado debate, ao punir elucubrações negacionistas a respeito do genocídio judaico. Historiadores de todas as posições se opuseram ao que então chamavam de sequestro da história pela memória. Segundo eles, não caberia ao direito, cedendo às pressões políticas de grupos organizados, ditar os limites do estudo histórico ${ }^{3}$.

$\mathrm{Na}$ introdução de sua mais famosa obra, Les Lieux de mémoire, o historiador francês Pierre Nora traça a distinção fundamental entre história e memória, ponto de partida para este artigo. Segundo o autor, enquanto a história seria a reconstrução sempre problemática e incompleta daquilo que já não existe, isto é, uma representação do passado, a memória seria um fenômeno sempre atual, ligado a um eterno presente, aberto à dialética da lembrança e da amnésia e, por isso, vulnerável a utilizações e manipulações diversas. Por ser afetiva, a memória é maleável, e se apega aos detalhes que lhe confortam, ao passo que à história caberia o papel analítico do discurso crítico. Operação intelectual e laicizante, a história pertence a todos e a ninguém e a isso deve sua vocação universal, ao passo que a memória é, por natureza, coletiva e individual. Se esta procura estabelecer um relato perfeito e absoluto, aquela não pode reconhecer nada além do relativo (NORA, I997, p.25) É certo que uma e outra compartilham a problemática central de representação de um objeto ausente, mas a maneira como cada uma delas procura sanar este problema as distancia, se não em seu ponto de partida, ao menos nos objetivos perseguidos.

É a partir desta distinção fundamental, temperada com a constatação incontornável de Paul Ricoeur, de que a memória é a matriz da história, guardiã da problemática da relação representativa do próprio presente no passado (RICOEUR, 2000, p. IO6) que devemos nos perguntar em que medida podemos falar em dever de memória, e em relação a quais eventos este deve ser evocado. A questão do modo de implementação deste dever, assim como da pertinência da 
contribuição jurídica nesta tarefa, embora de enorme relevância, não será aqui abordada, senão muito superficialmente. O que se procurará fazer, neste breve artigo, é primeiramente entender em que medida a concepção do passado se articula com a nossa visão do próprio presente e se projeta em direção ao futuro. Em seguida se buscará, por meio da análise proposta por Ricoeur de dois ensaios de Freud, identificar traços patológicos na formação da memória do indivíduo e tentar transpô-las para o debate público. A leitura aproximativa de Ricoeur e Tzvetan Todorov, fio condutor de todo o texto, nos ajudará a dar o passo seguinte, em direção à delimitação do dever de memória, abrindo o caminho para a discussão final, de saber quando o exercício deste dever pode constituir abuso.

\section{Uma Questão de Projeto}

Em um de seus ensaios sobre o revisionismo, Pierre Vidal-Naquet chama a atenção para a tentadora, porém duvidosa tendência que tem o historiador de escrever a história como uma tragédia clássica, cujo desfecho é antecipadamente conhecido. A colocação é particularmente pertinente ao tema, dada a forte carga emotiva que costuma acompanhar estudos sobre o genocídio judaico. De um lado e de outro não faltam os que expliquem o holocausto por meio de suposições com pouca ou nenhuma fundamentação histórica. Que as câmaras de gás nunca existiram, ou que o extermínio massivo dos judeus, e apenas deles, tenha sido um projeto pré-configurado por Hitler desde I9I9 são afirmações que se situam, diz o historiador, todas as duas, para além do processo histórico, encerradas em si mesmas e erigidas sobre uma estrutura mítica (VIDAL-NAQUET, I987, p.I4I) A metodologia da construção histórica constitui uma questão muito mais complexa do que se pretende um artigo como este, mas a dificuldade apresentada por VidalNaquet abre espaço para uma discussão que se situa menos no plano da história e mais na intersecção deste com o discurso memorialístico.

A concepção humana da história deve ser entendida como parte de um processo mais amplo de compreensão do tempo, enquanto fenômeno linear. É porque concebemos o tempo como uma linha reta, no lugar de tomá-lo por uma curva, que a história figura diante de nossos olhos como uma flecha, "ela se enraíza em uma memória e se organiza em torno de um projeto" (GUILLEBAUD, 2006, p.47). Por trás desta noção temporal se encontra, é inegável, a ideia de progresso, isto é, de que o tempo caminha em direção a algo.

Disso decorre a tentação, de que fala Vidal-Naquet, de encontrarmos razões dentro do passado que confirmem uma determinada concepção presente. 
Ora, se esta concepção se altera, não surpreende que também a leitura que fazemos da história se altere. Assim o diz Jean-Claude Guillebaud, ao afirmar que "nossa relação com o passado é largamente determinada por nossa visão do futuro; ela é sempre renegociável e reformável". Em outras palavras, "é sempre à luz de um projeto coletivo [...] que uma sociedade aprende a ler - ou a reler diferentemente - sua própria história" (GUILLEBAUD, 2006, p.48). Também por isso Ricoeur chama atenção para o fato de que é o próprio presente que se representa no passado.

Embora todas estas constatações valham tanto para a história, enquanto ciência humana, quanto para a memória, é no plano memorialístico que melhor podemos identificar a influência de um projeto coletivo na leitura do passado, dadas as características de maior maleabilidade desta em comparação com a história, tal como nos mostra Pierre Nora. A mobilização da memória é particularmente propícia à busca de uma reivindicação identitária e é por isso que a fragilidade da memória, enquanto objeto de manipulação ${ }^{4}$, deve ser entendida no contexto da problemática da identidade (RICOEUR, 2000, p.98), temática a ser abordada na próxima seção, quando falarmos em herança da violência fundadora.

Para Guillebaud, a explicação da explosão de memória que hoje vive a Europa passa necessariamente pela constatação de uma descrença no futuro. Uma crise política, nos termos daquela descrita por Benjamin Stora, e o questionamento implacável da própria ideia de progresso leva o homem contemporâneo à ruptura com a perspectiva de um futuro qualquer. E a renúncia deste implica, fatalmente, a ruptura com o tempo retilíneo, sobre o qual toda a concepção ocidental de história se ergue e do qual toma de empréstimo seu sentido. "É este desfacelamento silencioso da nossa representação do futuro que governa, de agora em diante, nossa relação com o passado, com a tradição, com a memória coletiva" (GUILLEBAUD, 2006, p.54). Em outras palavras, se nos voltamos para o passado memorial de maneira quase obsessiva, é porque nada esperamos do futuro. E hesitamos de maneira doentia, diz o historiador, entre uma glorificação retrospectiva e uma repetição desolada.

m seu livro La mémoire, l'histoire, l'oublie, Paul Ricoeur propõe a interpretação e aproximação de dois ensaios de Freud e sua transposição para o plano coletivo, como maneira de encarar a memória primeiramente sob uma perspectiva patológica para, num segundo momento, explorar as possibilidades de superação que se apresentam a uma sociedade.

4 O termo manipulação, tal como usado por Paul Ricoeur, não sugere a priori um uso ideológico da memória. Ele é utilizado antes para sublinhar uma diferença entre aquele que provoca a lembrança e aquele que de fato a tem. A possibilidade deste uso ideológico aparece na obra de Ricoeur como uma das formas de memória manipulada, a saber, o abuso da memória, mas não a única. 


\section{Trabalho de Memória e Trabalho de Luto}

Em sua leitura de Rememoração, repetição e perlaboração ${ }^{5}$, Ricoeur explicita a repetição, por parte do paciente, de uma lembrança recalcada, traduzida em forma de ação. "O paciente não reproduz (o fato esquecido) sob a forma de lembrança, mas sob a forma de ação: ele o repete sem evidentemente saber que o faz" (FREUD, I9I4, p.I684). A compulsão de repetição encontra nas resistências do recalcamento um obstáculo ao trabalho de interpretação e à continuação da análise. Face ao diagnóstico, Freud faz duas proposições, uma voltada ao analista, e outra ao paciente. Àquele, aconselha paciência para com as repetições supervenientes sob o abrigo da transferência, dado que esta criaria uma espécie de terreno intermediário entre a patologia e a vida real, arena onde a compulsão estaria autorizada a se manifestar livremente. Ao paciente, por sua vez, cabe encontrar a coragem de fixar sua atenção sobre as suas manifestações mórbidas, não mais considerando sua doença como algo de desprezível, mas encarando-a como um adversário digno de estima, como uma parte de seu próprio ser, fundada em motivos importantes e da qual poderá extrair valiosos ensinamentos para sua vida posterior (FREUD, I9I4, p.I686).

A ideia central nestes dois conselhos, ressalta Ricoeur, é a de trabalho, que sublinha não apenas o caráter dinâmico do processo, mas a colaboração que o permeia. O trabalho de rememoração se opõe à compulsão de repetição.

Já ao abordar Luto e melancolia ${ }^{6}$, Ricoeur aponta que é a propensão do luto à melancolia e a dificuldade daquele de se subtrair desta terrível neurose, que devem suscitar nossas reflexões posteriores sobre a patologia da memória coletiva e sobre as perspectivas terapêuticas abertas. Sendo o luto a reação à perda de uma pessoa amada, ou de uma abstração erigida em substituição desta pessoa, como a pátria, a liberdade, um ideal, a primeira questão que se coloca o analista é a de saber por que, em alguns pacientes, em lugar do luto, vê-se surgir a melancolia.

No trabalho de luto, o exame da realidade mostra que o objeto amado deixou de existir e demanda que a libido abandone suas relações com ele. Contra esta demanda surge uma resistência naturalíssima, pois sabemos que o homem não abandona de bom grado nenhuma das posições da sua libido, ainda que já tenha encontrado para ela uma substituição. [...] O normal é que o respeito à realidade vença (FREUD, I9I5, p.274).

5 ERINNERN, Wiederholen und Ducharbeiten, In: Gesammelte Werke, t. X, Francofort-sur-le-Main, S. Fischer Verlag, I9I3-I9I7, pp. I26-I36.

6 Trauer und Melancholie, In: Gesammelte Werke, t. X, op. cit. 
Em outras palavras, o trabalho de luto consiste precisamente na realização em detalhe de cada uma das ordens ditadas pela realidade. O que faz do luto um processo normal, em oposição à melancolia, é o fato de que, uma vez concluído o processo, o ego se encontra novamente livre e desinibido. É neste ponto que Ricoeur explicita a aproximação proposta entre o trabalho de luto e trabalho de rememoração. Assim como, no lugar de se lembrar, o paciente age, no lugar do luto, assume a melancolia.

Outro aspecto importante é o fato de que a melancolia se caracteriza psiquicamente por um estado de ânimo profundamente penoso, a cessação do interesse pelo mundo externo, a perda da capacidade de amar, a inibição de toda e qualquer atividade e a diminuição dos sentimentos de auto-estima a ponto de encontrar expressão em autorrecriminação e autoenvilecimento, culminando numa expectativa delirante de punição. Este quadro torna-se um pouco mais inteligível quando consideramos que, com uma única exceção, os mesmos traços são encontrados no luto. A perturbação da autoestima está ausente no luto; afora isso, porém, as características são as mesmas (FREUD, I9I5, p.276).

Ora, esta descrença no próprio ego em muito se assemelha ao abandono do futuro que a sociedade contemporânea apresenta, em sua obsessão por seu passado memorial e recusa à realização de um trabalho de memória reflexivo, composto não apenas pelo pensamento crítico, mas atento também para a noção de construção conjunta que tal exercício abriga. Neste sentido, a distinção proposta por Ricoeur entre rememoração por um lado e memorização por outro é esclarecedora: enquanto esta se caracteriza pela economia com que se limita a reter informações, abreviando o caminho do aprendizado, aquela agrega a reflexão ao seu processo.

Buscando então uma equivalência entre as situações patológicas descritas e a memória coletiva, Ricoeur propõe a seguinte diferenciação: enquanto a memória-repetição se caracteriza pelo excesso de evocações do passado ou pela ausência delas (trop ou trop peu de mémoire) e pela resistência à crítica, a memória-lembrança é fundamentalmente crítica. É por meio desta última que o trabalho de luto, bem como o trabalho de rememoração, se faz possível, e mais uma vez Ricoeur nos lembra da importância da colaboração entre analista e paciente neste trabalho, pois a transposição da esfera particular para a coletiva o faz sugerir que "os transtornos enfocados não são apenas sofridos, mas que somos responsáveis por eles, o que é comprovado pelos conselhos terapêuticos que acompanham a perlaboração" (RICOEUR, 2000, p.97, grifo nosso) A deturpação perversa deste trabalho em que o luto se une à rememoração pode 
aparecer sob a forma daquilo que o autor chama de abuso da memória, a ser abordado na seção final deste artigo ${ }^{7}$.

\section{Dever de Memória}

Estudos sobre a memória frequentemente dedicam uma linha à personagem borgeana de Irineo Funnes. Com efeito, Funnes, aquele que nada esquecia, sendo capaz de passar todo o dia a se lembrar do dia anterior, revivendo em tempo real cada detalhe do passado, atua nestes estudos como um contraponto à imperfeita seletividade da memória humana. O próprio Borges aponta a excepcionalidade de sua personagem ao colocar, nas palavras do narrador, a seguinte impressão: "Havia aprendido sem esforço o inglês, o francês, o português, o latim. Suspeito, contudo, que não era muito capaz de pensar. Pensar é esquecer diferenças, é generalizar, abstrair. No abarrotado mundo de Funnes não havia senão pormenores, quase imediatos" (BORGES, I942, p.I25).

Aprendemos com Borges que não apenas pensar, mas também viver, implica algum esquecimento, e o confinamento de Funnes, bem como sua prostração, é a prova de que uma memória absoluta é de todo incompatível com a vida. Freud nos ensina, contudo, que a compulsão de repetição advém de uma lembrança recalcada e que a libertação do ego passa pelo trabalho de rememoração. Está claro que não há incompatibilidade entre uma lição e outra. O que nos falta é entender em que medida a memória (coletiva) é necessária à vida de uma sociedade e quando ela se torna nociva. Em outras palavras, em que constitui o dever de memória e quando este pode se tornar abuso da memória ${ }^{8}$.

A esse respeito, Tzvetan Todorov aponta em seu ensaio Les abus de la mémoire algumas distinções fundamentalmente esclarecedoras, a primeira delas dizendo respeito justamente ao fato de que o resgate do passado, exercício essencial a toda sociedade, não deve contudo se confundir com o uso que dele se fará. "É supérfluo, diz o autor, se perguntar se se deve conhecer a verdade sobre o passado: a resposta, aqui, é sempre afirmativa. $O$ mesmo não se pode dizer,

7 A esse respeito, é preciso dizer que Ricoeur foi duramente criticado por ter "abandonado o dever de memória”. Para mais informações sobre o tema, ver: BADIOU, Le sujet supposé chrétien de Paul Ricoeur. À propos de La mémoire, l'histoire, l'oublie, In: Élucidation, n. 6-7, Éditions Navarin: 2003 e F. Dosse Travail et devoir de mémoire chez Paul Ricoeur, In La mémoire, pour quoi faire?, Paris, Éditions de l'atelier: 2006.

8 Poderíamos também falar, de maneira análoga e complementar, de abuso do esquecimento, como contrapartida igualmente patológica ao abuso da memória, mas este tema foi deixado de lado, em virtude das imprecisões que uma abordagem pouco cuidadosa poderia cometer ao comparar deliberadamente um e outro abusos sem se ater também diferenças, o que ultrapassaria o objetivo aqui assumido. 
no entanto, dos objetivos que se buscará atingir com a ajuda desta lembrança do passado" (TODOROV, I995, p.49).

Não muito diversa é a intenção de Ricoeur ao lançar mão de categorias

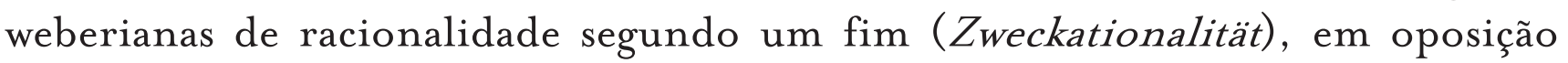
à de racionalidade segundo um valor (Wertrationalität) em paralelo com a "razão comunicacional" e "razão estratégica" de que fala Habermas (RICOEUR, 2000, p.97). É neste ponto de sua análise que o filósofo francês admite o estudo do uso ideológico da memória manipulada, admitindo que este encontra justamente na função seletiva da memória a ocasião e os meios de uma estratégia ardilosa.

Contudo, apresentando uma segunda distinção fundamental, Todorov nos mostra com clareza que, sendo a seletividade um traço constitutivo da memória, o que torna a memória manipulada especialmente ultrajante, e neste ponto ele se refere particularmente ao controle do passado pelo aparato estatal dos totalitarismos do século XX, não é o fato de estes regimes escolherem certos eventos do passado em detrimento de outros para integrar seu discurso histórico, mas sim o direito ao qual se arrogam de controlar a escolha destes elementos a serem retidos. A cada um, diz o autor, deve ser garantido o direito de buscar a verdade dos fatos sem sofrer punições por não aceitar a versão oficial do passado e, se esta é uma das garantias de um regime democrático, conclui, a assunção da inegabilidade de um evento qualquer - seja ele um crime contra a humanidade ou outro acontecimento do passado - não deve ser assegurada por uma lei, ainda que as intenções desta sejam boas. Não cabe ao Estado proibir ou permitir que cada indivíduo ou grupo da sociedade conheça e faça com que conheçam seu passado, dado que este é um direito indisponível e leis como a Gayssot são despropositadas na medida em que procuram ditar a História.

O direito à memória é assumido, pois, como um ponto de partida e, embora muito se tenha feito no sentido de demonstrar a legitimidade de tal direito, a clareza do argumento de Todorov parece suficiente para os propósitos deste artigo. No entanto, a prova da realidade nos mostra que, longe de ser um ponto pacífico nas sociedades, a questão memorial é tão mais complicada quanto diversos podem ser os discursos construídos em torno de um mesmo evento, e a existência de mais de um grupo afetado por um mesmo conflito pode abrir espaço para o que chamamos de guerra de memória ${ }^{9}$. Embora este conflito entre

9 Benjamin Stora trabalha este conceito em seu livro Les guerres des mémoires, no qual aborda mais especificamente o caso francês da guerra da Argélia (I954-62). Outros exemplos no entanto, podem ser citados, como a questão do genocídio armênio pelos turcos (I9I5). 
memórias agregue diversos fatores, e nenhum deles baste para atender sozinho à necessidade de pacificação, proponho aqui a abordagem de um destes aspectos, resultante de leitura aproximativa das análises de Todorov e Ricoeur: trata-se de saber quando o direito à memória se converte em dever de memória ${ }^{\mathrm{I}}$.

Se Todorov nos mostra claramente que a todos deve ser permitido resgatar o passado, bem como analisar livremente os critérios norteadores da seletividade memorial, não podemos contudo concluir que todos temos o dever de sempre fazê-lo. Afinal, o recalcamento de uma lembrança traumática parece igualmente legítimo, tanto mais porque recalcá-la não se trata, parece-nos, de uma opção deliberada daquele que viveu a experiência. A conclusão, a meu ver errônea e precipitada, que poderíamos tirar deste aparente conflito é de que, ainda que tenhamos direito à memória, o dever de fazê-la é facultativo, e cabe ao discernimento de cada um, ou de cada grupo, decidir quando dispor deste direito, realizando-o ativamente.

Aqui dois esclarecimentos se fazem necessários. O primeiro deles diz respeito à diferença fundamental, até este ponto negligenciada, entre a esfera individual e o plano coletivo. A decisão de não reviver diariamente os horrores de um acontecimento traumático deve caber a cada pessoa individualmente, e isto se torna evidente pelas palavras de Todorov:

O resgate do passado é indispensável; isso não quer dizer que o passado deve reger o presente, é este, ao contrário, que faz do passado o uso que quer. Haveria uma infinita crueldade em relembrar incessantemente a alguém os eventos mais dolorosos de seu passado; o direito ao esquecimento existe também (TODOROV, I995, p.24).

E para melhor ilustrar aquilo que defende, o autor evoca o exemplo de Euphrosinia Kersnovskaia, que, após doze anos passados em um goulag soviético, termina o relato de sua experiência se perguntando se não seria melhor que tudo aquilo vivido caísse em esquecimento.

IO A esse respeito, é preciso dizer que leituras diversas entendem o dever de memória como sendo anterior ao direito de memória. Segundo esta compreensão, o dever de um Estado de reconhecer seu passado não asseguraria necessariamente a cada indivíduo o direito a tal reconhecimento. A divergência entre uma visão e outra reside, a meu ver, em uma confusão. Trata-se de saber a quem cabe o dever de memória, se ao Estado ou aos cidadãos. É certo que Todorov foca sua passagem de direito em dever no indivíduo, e mais especificamente no indivíduo dono da memória. Mas não me parece incompatível com a sua posição que aqueles portadores do dever de memória sejam abrigados por um direito exigível frente ao Estado. Tampouco me parece que Todorov negue a participação estatal em políticas de memória apenas por assumir como ponto de partida destas a contribuição individual. 
Sem dúvida, parece-nos perfeitamente compreensível a recusa de grande parte dos sobreviventes de experiências concentracionárias, assim como de outras situações degradantes, como a tortura, em falar de suas vivências. No entanto, a consideração da patologia individual numa escala coletiva parece apresentar uma demanda diversa, que pode ser melhor compreendida pelas ideias de trabalho de rememoração e trabalho de luto, tal como apresentadas por Ricoeur. Não por acaso este sublinha a importância da cooperação no processo de análise, aconselhando não apenas o paciente, mas também o analista. Em uma passagem de seu texto acima citada ele explicita esta interação ao afirmar que somos todos responsáveis pelos problemas encontrados no processo de perlaboração, e que a experiência analítica se encontra precisamente na articulação do lado ativo, aquele que exercita a memória, de seu lado passivo. Neste sentido, Ricoeur afirma que é sobretudo no plano da memória coletiva que a coincidência entre trabalho de luto e trabalho de rememoração faz todo seu sentido (RICOEUR, 2000, p.96)

A passagem para a esfera coletiva deve ser entendida a partir da bipolaridade que há entre identidade pessoal e identidade comunitária. A relação fundamental da história com a violência, isto é, a existência de conflitos na formação da sociedade $^{\mathrm{II}}$, faz com que sejamos, desde sempre, confrontados com a ideia de perda. "A glória de uns foi a humilhação para outros. À celebração, de um lado, corresponde a execração do outro. Assim se armazenam, nos arquivos da memória coletiva, feridas simbólicas que pedem cura" (RICOEUR, 2000, p.99).

Para falarmos do plano coletivo, devemos considerar ainda um novo elemento, ausente nas ideias de trabalho de rememoração e trabalho de luto. Trata-se da ideia de imperatividade. A noção de dever de memória, portadora desta imperatividade, estaria, neste caso, duplamente caracterizada: de um lado, o dever se impõe de fora ao desejo e, por outro, exerce uma pressão interna, sentida subjetivamente como obrigação. Ora, a reunião destes dois traços se dá, ao menos da maneira menos discutível, na ideia de justiça, objeto da próxima seção. É neste sentido que podemos já adiantar que nem todas as formas de memória são objeto do dever, mas tão somente aquelas ditas justas.

$\mathrm{O}$ segundo esclarecimento que me parece fundamental se encontra na questão de saber para quais acontecimentos a memória se apresenta como um dever. Neste ponto, Todorov é claro ao dizer que "quando os eventos vividos por um indivíduo ou por um grupo são de natureza excepcional ou trágica, este

II Ricoeur adota uma análise hobbesiana da violência como inerente à própria origem da sociedade, o que constituiria, para ele, uma herança que se estende até os dias de hoje. A despeito de quaisquer ressalvas que esta concepção possa merecer, acredito que a ideia da perda como um elemento constante e comum a toda sociedade, e, consequentemente, a ideia de um trabalho de luto que se faz necessário para cada perda, se mantêm relevantes. 
direito torna-se um dever: o de se lembrar e de testemunhar" (TODOROV, I995, p.I6, grifo nosso). O mesmo pode ser extraído da leitura que Ricoeur faz da teoria freudiana, nos dois ensaios em questão. Se no primeiro deles o tema é justamente a lembrança de um acontecimento traumático que, recalcada, passa a ser traduzida na forma de ação, comprometendo o ego e condenando-o à repetição, no segundo temos como ponto de partida a perda de um objeto amado. Parece claro que este acontecimento seja traumático em alguma medida, assim como o é o acontecimento cuja lembrança se recalca. É neste tipo de situação, afirma Todorov, em que a vida perde para a morte, que a memória deve ganhar ao combater o aniquilamento ${ }^{\text {I2 }}$ (TODOROV, I995, p.I6).

\section{A Memória Como Justiça}

Já vimos que, se o direito à memória deve ser garantido a todos, dado que o resgate do passado e a busca pela verdade dos fatos são exercícios fundamentais, o dever $^{13}$ de memória não se apresenta como a contrapartida necessária a todo e qualquer caso, mas somente àqueles decorrentes dos esclarecimentos apresentados acima. No entanto, uma última dificuldade se apresenta. Sabemos que, ainda que na esfera unicamente pública, e no que tange a acontecimentos indubitavelmente traumáticos, alguns usos da memória podem servir a propósitos espúrios de vingança e revanchismo ${ }^{\mathrm{I} 4}$. Uma vez estabelecida à legitimidade do direito à memória, bem como a necessidade de seu dever, devemos buscar agora compreender em que medida o uso do passado também se sujeita a restrições.

Neste momento, uma terceira e última distinção feita por Todorov permite a compreensão da questão. Trata-se da diferença entre uma leitura literal do passado e uma leitura exemplar deste. A leitura literal, diz o autor, resguarda o acontecimento traumático em sua literalidade na medida em que suas particularidades são privilegiadas em detrimento daquilo que ele compartilha com

I2 Para uma crítica contundente a este predomínio de eventos traumáticos na memória coletiva, ver: FINKIELKRAUT, La Nouvelle imortalité, In: La mémoire, pour quoi faire? Paris, Éditions de l'atelier: 2006. Neste ensaio, Finkielkraut critica o "criminocentrismo", protagonizado pelo "hitlerocentrismo" que, segundo ele, ocupa a posição central, senão única, no debate atual acerca da representação do passado.

I3 Em razão da distinção traçada entre o dever de memória a ser realizados por indivíduos e aquele que caberia ao Estado (nota II), tema que por si só mereceria um estudo mais cuidadoso, escolheu-se neste artigo falar da primeira das concepções, sem se negar, contudo, que ela leve, indubitavelmente, à segunda forma. I4 A este propósito, Todorov oferece em seu livro alguns exemplos, tais como a justificativa histórica dada pelos servos a sua agressão contra outros povos da ex-Yoguslávia, ou o desejo de "não esquecer e nem perdoar" alegado pelos irlandeses do norte, em sua vendeta interminável contra os demais irlandeses. 
situações diversas, de modo que o evento se mantém intransitivo, isto é, incapaz de ir além de si mesmo. Há, nesta forma de leitura, uma contiguidade temporal entre aquele indivíduo ou grupo que sofreu o traumatismo e os que o procedem, sendo as consequências deste traumatismo estendidas a todos os momentos de suas existências.

Em contrapartida, a leitura exemplar do passado, semelhantemente ao processo analítico de rememoração e domesticação de uma lembrança recalcada, abre a lembrança à analogia e à generalização, de modo que lições possam ser delas extraídas. A justificação das analogias se sobrepõe à necessidade de afirmação identitária, de modo que a contiguidade entre aquele que sofreu o traumatismo e os membros posteriores daquele grupo é posta de lado em nome da exemplaridade do acontecimento.

A valorização da singularidade do evento traumático, característica da primeira forma de leitura, faz lembrar a incapacidade de Funnes de abstrair, esquecendo diferenças. A insuperabilidade do evento nos remete também à propensão melancólica, que se sobrepõe ao trabalho de luto. Não se cumpre o trabalho de abandono dos investimentos pelos quais a libido continua vinculada ao objeto perdido até que a perda esteja definitivamente interiorizada. O presente é, afinal, submetido ao passado e há uma sugestão de fantasmagoria nesta maneira de leitura das reminiscências, que Todorov passa a chamar de memória tout court, e que podemos apresentar em paralelo com a noção de memória-repetição de Ricoeur. Neste caso, ironicamente, é o passado que serve ao recalcamento do presente, e este recalcamento, diz o autor, não é menos perigoso do que o outro, já visto.

Por outro lado, ele afirma o caráter libertador da leitura exemplar do passado, análoga, por sua vez, à memória-lembrança e que Todorov denomina de justiça. Nela, o passado se torna um princípio de ação para o presente, e a memória de eventos traumáticos será tão mais valiosa quanto mais útil for no combate a outros eventos. A escolha pela denominação de justiça não é casual. Para Todorov a impessoalidade decorrente da generalização da ofensa particular é fundamental na medida em que é por meio dela que chegamos à possibilidade de uma "lei impessoal, aplicada por um juiz anônimo e posta em prática por jurados que desconhecem a pessoa ofendida, assim como o ofensor" (TODOROV, I995, p.32) O autor não nega, é certo, o sofrimento gerado pela redução das vítimas à generalização, sobretudo pelo fato de que o que lhes passou é tão único quanto qualquer acontecimento, mas assume que tal sofrimento constitui o preço a pagar pela justiça. Mais uma vez, a distinção entre a escala individual e coletiva é fundamental, pois, se no debate público a comparação entre acontecimentos é salutar, para o indivíduo, ela pode funcionar como uma ofensa. 
A "arrogância da razão" pode ser, segundo o autor, insuportável ao indivíduo, para quem a intensidade da experiência vivida continua superlativa e absoluta. Ora, esta incomparabilidade de cada experiência, se estendida à esfera coletiva, compromete por completo a capacidade de dela se retirarem lições. É preciso que algo em comum possa ser vislumbrado para que a coletividade possa aprender com o passado.

A esta altura, podemos entrever na análise de Todorov uma dimensão moral que, embora permeie todo o seu texto, se explicita por completo pela frase com que ele termina o capítulo sobre a exemplaridade.

O trabalho do historiador ${ }^{15}$, como todo trabalho sobre o passado, não consiste nunca em estabelecer fatos, mas sim em escolher alguns dentre eles como sendo mais salientes e mais significativos que outros, em pô-los em seguida em relação entre si; ora, este trabalho de seleção e de combinação é necessariamente orientado para a busca, não da verdade, mas do bem(TODOROV, I995, p.50).

A questão, para ele, não estaria em negar qualquer objetivo externo à pesquisa histórica, mas na assunção do melhor dentre os objetivos. Paul Ricoeur não deixa de manifestar sua oposição à colocação alternativa de Todorov entre bem e verdade. Mas parece concordar com a dimensão moral que este atribui, ou: antes reconhece, na construção memorial. Conforme já vimos, é precisamente o caráter imperativo da ideia de justiça que propicia a transposição da esfera individual dos trabalhos de rememoração e de luto para a esfera coletiva. "É a justiça que, extraindo das lembranças traumatizantes seu valor exemplar, transforma a memória em projeto; e é este mesmo projeto de justiça que dá ao dever de memória a forma do futuro e do imperativo" (RICOEUR, 2000, p.IO7). Para além do trabalho de rememoração e do trabalho de luto, aos quais se apresenta como um terceiro termo articulado, o dever de memória se estende às duas dimensões mais profundas da memória, postas em paralelo ao longo da obra de Ricoeur, a saber, sua dimensão veritativa - "sobre o signo da fidelidade epistêmica da lembrança em relação ao que realmente aconteceu" - e sua dimensão pragmática - concernente ao uso da memória, enquanto prática, ou técnica de memorização.

I5 A figura do historiador, como detentor do conhecimento histórico, não deve, a meu ver, ser contraposta àquela dos aplicadores da memória. Embora a distinção traçada por Pierre Nora entre história e memória seja por demais conhecida e aceita para não ser levada em consideração, parece-me que neste caso, no lugar do reconhecimento desta dicotomia, o que Todorov procura sinalizar é a participação do historiador na construção de um discurso memorial moral, contribuindo para o que Ricoeur chama de memória histórica, em contraponto à memória individual e coletiva. 
Três são as características, segundo Ricoeur, que dão força à ideia de justiça, seja no plano das dimensões veritativa e pragmática, seja em relação aos trabalhos de memória e de luto. Primeiramente, o fato de ser a justiça, dentre todas as virtudes, aquela que é, por excelência, voltada para o outro. Trata-se do "componente de alteridade de todas as virtudes, que ela (a justiça) retira do seu curto-circuito entre si mesmo e si mesmo" (RICOEUR, 2000, p.IO8). Em segundo lugar, um novo conceito é apresentado pelo filósofo, a saber, a noção de dívida. Segundo ele, nós devemos parte do que somos aos nossos precedentes, não podendo o dever de memória se restringir à conservação de traços puramente materiais do passado. É preciso que também o sentimento de obrigação para com os que vieram antes integre este dever. Finalmente, e como desdobramento do segundo elemento, tem-se que, dentre todos diante dos quais somos endividados, deve haver uma prioridade moral às vítimas.

\section{Abusos da Memória}

Com isso terminamos a análise do que constitui o dever de memória, delimitando, dentre um universo possível de acontecimentos, aqueles que parecem mais apropriadamente próximos ao objeto deste dever. Resta-nos agora analisar sua face oposta, isto é, distorções que dele podem decorrer. Ao longo da análise, que se dividirá em dois casos mais expressivos e, portanto, não exaustivos, perceberemos que, embora à primeira vista os dois casos pareçam pertencer ao rol das memórias ditas justas, ambos apresentam alguma forma de perversão.

\section{VI.I. Competição entre vítimas}

A prioridade às vítimas que acabamos de ressaltar como um dos elementos constitutivos da força da justiça é a primeira fonte de distorção que podemos apontar. Esta ocorre, podemos dizer, quando, tendo tido seu passado e seu sofrimento reconhecidos, um indivíduo, ou grupo, se apega a seu estatuto de vítima sem abrir mão, na esfera pública, da singularidade de sua vivência. Desta recusa à generalização e, portanto, à possibilidade de comparação, decorre que nenhuma outra dor pode ser equiparada à própria. Toda tentativa de aproximação se torna ofensiva, na medida em que eleva o sofrimento de algum outro grupo a um grau que deve permanecer único, exclusivo daquele grupo e, no limite, apenas um deles poderá ser considerado vítima. A outra face desta mesma concorrência se dá pelo sentido oposto deste mesmo caminho: no lugar da recusa à comparação, 
a insistência nela como forma de afirmar a própria dor como digna de tanta ou mais atenção e reconhecimento do que a de determinado grupo.

Em I993, no museu de Auschwitz, na Polônia, organizou-se um congresso, do qual Todorov foi chamado a participar, conforme nos conta em seu ensaio, cujo tema era "A unicidade e incomparabilidade do holocausto". Como contraponto a este posicionamento, mas ainda na mesma rota, temos a afirmação de Louis Farrakhan, chefe do grupo militante estadunidense Nation of Slam citado por Todorov, segundo o qual "o holocausto do povo negro foi cem vezes pior do que o holocausto dos judeus". Uma e outra posição tem em comum o fato de que a reivindicação de povo mais desfavorecido leva à negação do sofrimento alheio, e nisto reside a perversão da ideia de justiça, vista há pouco como virtude que por definição reconhece e assume a alteridade.

Não é de todo incompreensível, diz Todorov, esta concorrência pelo título de vítima absoluta. Afinal, se ninguém quer ser uma vítima, a todos parece atraente a ideia de ter sido uma no passado, pois o estatuto de vítima confere a seu portador o direito de se queixar, de protestar, de reclamar. E quanto maior tiver sido a ofensa no passado, maiores serão os direitos da vítima, ao ponto de se abrir para esta uma "linha de crédito inesgotável" (TODOROV, I995, p.57), tanto por meio de reparações materiais quanto pela dívida simbólica. Sobretudo esta dimensão não se esgota.

A lógica "dolorista" da postura de vítima também é denunciada por Benjamin Stora. Para ele, esta posição se torna nociva na medida em que conduz à passividade e a um encerramento identitário. "As interpelações comunitaristas, diz, somente serão positivas na medida em que fizerem avançar as coisas. $O$ que importa, in fine, é tornar distantes as lembranças de um conflito cruel" (STORA, 2007, p.66). O cerne da crítica a tal comportamento exclusivamente autorreferenciado reside sobretudo no fato de que, como bem expressa Todorov, 'a repetição ritualística do 'não se deve esquecer' não tem nenhuma incidência visível sobre processos de purificação étnica, torturas e execuções massivas que se produzem ao mesmo tempo, no interior da mesma Europa" (TODOROV, I995, p.6o.)

\section{VI.II. Culto à memória}

Podemos chamar a segunda e última forma de abuso de memória aqui abordada de culto à memória e para compreendê-la devemos nos lembrar do que nos diz Jean-Claude Guillebaud a respeito da ruptura com um tempo linear e a descrença atual na ideia de futuro, bem como da distinção que Nora nos oferece entre história e memória. 
A obsessão pelo passado, traduzida na forma de uma celebração incessante no presente eterno, pode ser entendida como mais uma perversão da lógica proposta pelo dever de memória. O diagnóstico de Nora, citado por Ricoeur, é claro: "É a própria dinâmica da comemoração que se inverteu, o modelo memorial levou a melhor sobre o modelo histórico e, com ele, um uso completamente diferente do passado, imprevisível e caprichoso ${ }^{\mathrm{I}}$ " . Vemos então a história a serviço da memória, e mais do que nunca, o temor de Vidal-Naquet de recontar o passado como uma tragédia clássica encontra razão de ser. Assistimos à sacralização do passado, e seu encerramento na forma de um todo acabado, perfeito, que deve ser eternamente repetido na forma de ritos comemorativos. "A inversão que está na origem da obsessão comemorativa, diz Ricoeur, consistiria na recuperação das tradições defuntas, de fatias de passado das quais estamos separados" (RICOEUR, 2000, p.IIO). Em outras palavras, é a própria era atual que se tornou comemorativa, para além do espaço legítimo tradicionalmente atribuído à comemoração.

Benjamin Stora parece compartilhar deste diagnóstico ao alertar para o peso da história, que "exerce por vezes uma tirania assustadora que nos torna impotentes. $O$ sufocamento por uma repetição de um passado cruel freia a transmissão da narrativa coletiva, e nos encurrala em uma reconstrução do sentido da história por vezes duvidoso" (STORA, 2007, p.65).

Mas o efeito deste culto imperguntado à memória se estende, diz Todorov, para além de nossa concepção do passado, levando a uma alarmante cristalização do presente. "Atividades outrora utilitárias tornam-se agora objeto de contemplação”. Museus são inaugurados a torto e a direito em toda a Europa, como o museu do crepe, criado na região francesa da Bretanha, pondo em evidência aquilo que Stora chama de trop-plein mémoriele Guillebaud denomina maniaquerie commémorative. Trata-se de um sintoma, afirmam os dois, de nossa pane no projeto coletivo de futuro. "A viagem perpétua ao passado pessoal deixa ver uma angústia face ao futuro" (STORA, 207, p.65).

Ora, esta cristalização do presente, que, na visão pouco otimista de Guillebaud pode levar à saída da História, parece ir ao encontro da postulação de que são objetos do dever de memória eventos do passado em alguma medida traumáticos. Para além disso, a noção de justiça parece inteiramente deixada de lado no momento em que a celebração memorial deixa de se voltar para a exemplaridade e passa a servir à única função de afirmação identitária. 


\section{Considerações Finais}

Ao fim de nossa análise aproximativa entre Paul Ricoeur e de Tzvetan Todorov acerca da memória, podemos ver que, a despeito das diferentes propostas que cada um apresenta com sua obra, a proximidade entre uma concepção e outra é inegável, e sua centralidade reside naquilo que ambas não apenas reconhecem como defendem, a saber, a dimensão moral por trás de um discurso memorial qualquer. Memória-repetição ou leitura literal, memória-lembrança ou leitura exemplar, são termos correlatos que buscam dar conta justamente da moralidade que deve haver no resgate do passado, assim como no uso dele - e aqui mais um paralelo é possível, com as dimensões veritativa e pragmática da memória. É esta segunda dimensão pragmática que, abrindo espaço para a analogia e generalização, procura resgatar o discurso memorial de seu ponto de partida multiculturalista e intransitivo. Apresenta-se assim uma via de universalização do particular que supera a mera afirmação identitária por meio de uma forma específica de memória, a justiça.

No que diz respeito aos abusos de memória, uma última advertência se faz fundamental. Assim como a memória está sujeita a um uso ideológico que consistiria precisamente no seu abuso, também este pode ser manipulado em favor do silêncio. Que nada se diga para que não se incorra em um abuso da memória é talvez a forma mais perversa de abuso do esquecimento, e o risco deste existe sempre que a leitura de textos originais for adaptada a contextos diversos daqueles em que foram escritos. É sobretudo por isso que se resistiu tão completamente a comparações com o caso brasileiro, no qual o trabalho de memória se mostra ainda recente. A colocação de James L. Cavallaro, vice-presidente do Conselho de Justiça global, parece extremamente elucidativa neste sentido: para ele, é preciso "ter a possibilidade de ler a página antes de virá-la".

\section{Referências Bibliográficas:}

BORGES, Jorge Luis. Ficções. Porto Alegre, Globo, 1972.

FREUD, Sigmund. Edição standart brasileira de obras completas de Sigmund Freud. Vol. XIV. Rio de Janeiro, Imago, I974.

FREUD, Sigmund. Obras completas. 4a ed., Vol. 2, Biblioteca Nueva, Madrid, I99I. 
HOUZIAUX, Alain (dir). La mémoire, pour quoi faire? Paris, Éditions de l'atelier, 2006.

NORA, Pierre (dir). Les Lieux de mémoire. Paris, Gallimard, I997.

RENAN,Ernest. Q'est-ce qu'une nation?, I882. Disponível em <http:// www.bmlisieux.com/archives/nationor.htm>

RICOEUR, Paul. La mémoire, l'histoire, l'oublie. Paris, Éditions du Seuil, 2000.

STORA, Benjamin. La guerre des mémoires - entretiens avec Thierry Leclère. Paris, Éditions de l'aube, 2006.

TODOROV, Tzvetan. Les abus de la mémoire. Paris, Arléa, I995.

VIDAL-NAQUET, Pierre, Les assassins de la mémoire. Paris, Éditions la découverte, 2005 .

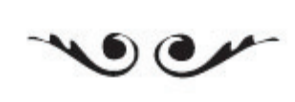

Rita Mattar é graduanda em Direito pela USP.

E-mail: ritamattar86@yahoo.com.br 